\title{
BETWEEN TWO WORLDS
}


By the same author

The Crazy Fabric: Essays in Irony

The Inimitable Dickens: A Reading of the Novels

Dickens: (Modern Judgements series) (editor)

Dickens: Bleak House (Casebook series) (editor) 


\section{BETWEEN TWO WORLDS}

Aspects of Literary Form

A. E. Dyson

Macmillan Education 


\title{
(C) A. E. Dyson $197^{2}$
}

Softcover reprint of the hardcover 1st edition 1972

All rights reserved. No part of this publication may be reproduced or transmitted, in any form or by any means, without permission.

\author{
First published 1972 by \\ THE MACMILLAN PRESS LTD \\ London and Basingstoke \\ Associated companies in Toronto Dublin \\ Melbourne Johannesburg and Madras
}

Library of Congress catalog card no. 79-1 83545

SBN 331131312

ISBN 978-1-349-01311-1

ISBN 978-1-349-01309-8 (eBook)

DOI 10.1007/978-1-349-01309-8 
For

GEORGE AND TINA COLE 


\section{Contents}

Preface and Acknowledgements ix

I Between Two Worlds: Prologue I

2 Virtue Unwavering: Milton's Comus I5

3 The Last Enchantments: Arnold's The Scholar Gipsy $4 \mathrm{I}$

4 Murderous Innocence: James's The Turn of the Screw 53

5 The Stranger God: Mann's Death in Venice 81

6 Faith among the Ashes: Scott Fitzgerald's

The Great Gatsby 100

7 Trial by Enigma: Kafka's The Trial II4

8 Eagles and Trumpets: The Transmuted Experiences of Literature 135

9 Between Two Worlds: Epilogue I50

Index $\quad \mathrm{I} 53$ 


\section{Preface and Acknowledgements}

This book is about literature, not about criticism, and I have tried to avoid 'the critical debate'. But a few general acknowledgements seem called for, and I am glad to name the critics who have influenced me most. First (among the moderns) Northrop Frye and C. S. Lewis; then, I think, the Geneva School, more indirectly than directly - Marcel Raymond, Georges Poulet, Jean Rousset, Jean-Pierre Richard, Jean Starobinski, and very particularly Albert Béguin, whose incarnational language links literary criticism most usefully outwards to the universal quest for religion, rather than inwards to the abortive romantic quest for the 'self'. Helen Gardner and Maynard Mack write beautifully, and often wisely; Frank Kermode's is a sparkling mind with which to disagree.

To name other living critics might be invidious, in times when so much good as well as bad criticism abounds. My more distant and chief debts are to T. S. Eliot, Coleridge and the whole tradition of literary Platonism and neo-Platonism, not forgetting - as I hope will be apparent - Plato himself.

The idea of this book has been in my mind for fifteen years, and parts of it have been published in earlier forms. I should like to thank the editors of Essays and Studies 1955, Essays and Studies 1967, Modern Fiction Studies, Review of English Literature and the Twentieth Century, and my co-editor of the Critical Quarterly, in whose pages material included here has appeared. All the chapters except the most recent one (on Mann's Death in Venice) have been extensively revised and rewritten, and the earlier versions are now superseded.

My thanks are also due to the many friends and students with whom I have discussed these topics over the years. The ideas and analyses are my own, but I have incurred more debts than I could record, or even remember. 